7. Chevalier G. Clochemerle. Paris: Le livre de poche, 2016. $384 \mathrm{p}$.

8. Le Trésor de la Langue Française informatisé. URL: http://www.cnrtl.fr/definition.

9. Michel C. Patois et français régional dans Clochemerle de Gabriel Chevalier. Revue de linguistique romane. 2004. №68. P. 475-497.

УДК 811.161.1'37

DOI https://doi.org/10.32782/tps2663-4880/2020.13-1.28

\title{
COMPOSITION AND GENERAL CHARACTERISTICS OF TEXT CATEGORIES
}

\section{СКЛАД ТА ЗАГАЛЬНІ ХАРАКТЕРИСТИКИ ТЕКСТОВИХ КАТЕГОРІЙ}

\author{
Suvorova S.A., \\ orcid.org/0000-0001-5341-2963 \\ Candidate of Philological Sciences, Assistant Professor, \\ English Language Teacher at the Department of Foreign Languages \\ Prydniprovska State Academy of Civil Engineering and Architecture \\ Chyghykova I.V., \\ orcid.org/0000-0003-2722-3258 \\ English Language Teacher at the Department of Foreign LANGUAGES \\ Prydniprovska State Academy of Civil Engineering and Architecture \\ Halchenko I.O. \\ orcid.org/0000-0003-4700-9937 \\ English Language Teacher at the Department of Foreign Languages \\ Prydniprovska State Academy of Civil Engineering and Architecture
}

In this article, an attempt was made to determine the composition and general characteristics of text categories, as well as to determine the differences between the topic and thesis. Also, we tried to analyze the functional and stylistic modifications of selected topics and theses. Taking into account the analysis of concepts, topic and thesis, a preliminary discussion of text concepts is required. The language components of the given text category are single nominative types: words and nominative words. Understanding the "main nomination" is the whole text, is necessary to introduce the most significant nomination in this text. The main text in the text can be basic one and can be with additional nomination. Taking into account the sequence of placement of units of the thematic chain in the text, the nomination that opens the chain will be called primary and all others secondary. In the lexico-stylistic aspect, the thematic composition of their chains as a whole has no limitations. Here, units of any style and emotionally expressive markings are possible, usually used and limited in use, literary and non-literary, modern and outdated. There are two groups of logical connections: logical and compound-logical. The first is links that indicates the type and nature of previous or subsequent information, the actual significant fragments of links. Distinguishing information and objective-subjective-logical information as the main types, we will name the most common types of information segments of the text. The informational role of the text fragment is determined by its content, which depends primarily on the lexical composition of the fragment, as well as on the sequence of fragments and their combined content.

Key words: thesis, text, thematic groups, communication, text category, meta-events of the text, functional styles.

У статті була зроблена спроба визначення складу і загальної характеристики текстових категорій, а також визначення відмінностей між темою і тезою. Також, ми спробували проаналізувати функціональні та стильові модифікації обраних тем і тез. Беручи до уваги аналіз понять, тема і теза, потрібно попереднє обговорення текстових понять. Мовні складові даної текстової категорії - одиниці номинативного типу: слова і номінативні словосполучення. Тема тексту знаходить вираз у референціально або значимо об'єднаних словникових групах за своїм складом. Поняття «основна номінація» - власне текстове, що виводиться із значущості номінації в даному тексті. Основний в тексті може виступати як базова, так і будь-яка з додаткових номінацій. 3 урахуванням послідовності розміщення одиниць тематичної ланцюжка в тексті, номінація, що відкриває ланцюжок, буде називатися первинної, а всі інші - вторинними. У лексико-стилістичному відношенні склад тематичних ланцюжків в цілому не має обмежень. Тут можливі одиниці будь-якої стильової і емоційно-експресивного маркування, загальновживані і обмежені по вживанню, літературні та нелітературні, сучасні і застарілі. У складі логічних зв'язок виділяються дві групи: власне логічні і, композиційно-логічні. До першої відносяться зв'язки, які вказують на тип і характер попередньої або наступної інформації, на власне змістовні зв'язку фрагментів. Розрізняючи в якості основних типів інформації об'ектівнологіческую і суб'єктивно-логічну, назвемо найбільш часто зустрічаються види інформаційних відрізків тексту. Інформаційна роль того чи іншого текстового фррагмента визначається його змістом, яке залежить перш за все від лексичного складу фрагмента, а також послідовністю розташування фрагментів і сукупним їх змістом.

Ключові слова: теза, текст, тематичні групи, комунікація, текстова категорія, метаподії тексту, функціональні стилі. 
Thematic chain of the text, along with the author's intention, is an essential and necessary attribute of any text. This is an extralinguistic factor that enters the core of the text and largely determines its structure [Mete et al., 1981]. Distinguishing between topic and thesis, text, we mean by subject the subject of speech, acting as the subject of the thesis of the text (the thesis is formed by predicting the subject). The theme and thesis of the whole text normally maintain their unity throughout the entire text; let us recall the statement adopted as a methodological principle in rhetoric: "One text - one thought". Considering the topic as the subject of verbal communication, we note that the concept of the topic does not stand outside the text pragmatist. "The connection of the topic with the subject of speech involves taking into account the mental side of the phenomenon" [Rizun, 1987, p. 33]. Another important observation for us is to emphasize the closest connection between the topic and purpose. "A topic is a convoluted content that is comparable to a plan" [Novikov, 1983, p. 23], therefore, through the concept of a topic, the connection between the text is understood not only with its denotation (reflected reality), but also with its subject (author). The theme of the text finds expression in the referentially or significally united vocabulary groups in its composition - in thematic groups, the totality of which forms a text field of thematic integrity. For thematic groups, the immediate names of the subject of speech are semantically and structurally most important. These are elementary nominations [Gack, 1977, p. 257], which constitute the main type of all existing nominations. The set of designations for a certain subject of speech (in the text, in addition to the main subject of speech, there always exists a number of additional subjects and, accordingly, subtopics), presented for some length of the text, is called a nomination chain [Gack, 1972]. The main nomination chain runs through the entire text and represents the topic of the whole text, while additional nomination chains determine the volume of subtopics. The main nomination chain contains the name of the topic of the whole text, allows you to distinguish the main information from the secondary, that is, it is an important concept in terms of content, theory and methodology. The main nomination chain of the text is denoted by the term "subject chain" and is considered in this paper as a linear text category. The general typology of nomination chains is as follows. The unity of the semantics of the nomination chain lies in the generalized meaning "the subject of speech of the whole text", which is filled with specific content only in a specifictext. The language components of this text category are units of the nominative type: words and nominative phrases. The substantial unity of the thematic chain is based on the reference identity of the nominations (in the chain different designations of the same real subject are presented) or on their identificative identity (the nominations of the chain are equivalent concepts). The linguistic expression of the same signified may be identical (repeated nomination) or different. The basic, basic nomination of the chain is the lexical unit in its primary function [Gak, 1977, p. 243]. This is a proper name (if the object has it), a term, or, most often, a direct nomination, a neutral common word. The base nomination stands out on linguistic, pre-textual grounds. Of the number of available nominations, the basic one is that I can be an identifier with respect to all the nominations of the chain, since the subject of speech of the text most accurately and directly designates. All other nominations in relation to the base are additional. Additional nominations are divided into three types: lexically new, which include synonyms of the basic nomination, "reference identical nominations and taxonomic nominations - designations of generic concepts in relation to the basic; transforms - various transformations of the basic nomination, including collapsed and expanded nominations, as well as grammatically transformed designations; substitutes - substitutes for the basic nomination, incomplete out of context, pronouns. In this article relies on the description of this typology on general theoretical works in the nomination of V. G. Gak as well as special studies in the field of lexical links of the text: Sevbo, Akishina, Loseva, Smetanina, Otkuyshikova, Gorelikova, Magomedova, Maydanova. Any unit of a thematic chain, as basic, as additional, can be repeated in the text and play a more or less significant textual role. Depending on the number of repetitions, as well as the location of the repeating units in significant parts of the text various nominations of the chain are put forward in it more or less significant place. The most frequent unit of a thematic chain, appearing, among others, in key places of the text, is the main nomination. The concept of "main nomination" is actually a text, deduced from the significance of the nomination in this text.

The main text in the text can be either basic or any of the additional nominations. Given the sequence of placement of units of the thematic chain in the text, the nomination that opens the chain will be called primary, and all others - secondary. In the lexical-stylistic sense, the composition of thematic chains as a whole has no restrictions. Here units of any style and emotionally expressive marking are possible, commonly used and limited in use, literary and non-literary, 
modern and outdated. Not that within a separate functional style, where the specific composition of the theme chain is determined by the theme of the text, the author's intention and the requirements of the style. Finding out the volume of the latter is the purpose of the analysis. The chain of thought, the general meaning of the text is ascertained by the addressee gradually, on the basis of accumulation and analysis of information of its minimal semantic parts - microtexts. Accordingly, the text itself can be considered as a reflection of the process of the formation of meaning [Bart, 1980, p. 397]. The informational role of one or another text fragment is determined by its content, which depends primarily on the lexical composition of the fragment, as well as the sequence of arrangement of the fragments and their combined meaning. The delimitation of information segments of the text due to this is not marked (it does not have special means of linguistic expression), as well as absolute, for example, microtexts are not always located in the text in the order of logical sequence: it is known that there is a logic of reasoning and presentation logic, not always coinciding with each other [Semantic perception, 1976, p. 68]. A scientific description of such methods of informational division of the text is possible only on the basis of system knowledge of a specific subject area, reflected in the text [Otkupschikova, 1982, pp. 79-80]. In addition to the aforementioned means, in the developed literary language there is a significant set of special language units indicating the nature of subsequent or previous information, the semantic relationship of the input information fragment to another fragment or to the whole text, etc., which show the consistent development of the author's intention in disclosing selected topics and due to which the logical integration of various fragments into larger semantic blocks of the text is carried out. These units include lexical and lexical-syntactic means (unions and allied words, adverbs with communication semantics, full-valued lexical units of "progressive-logical" semantics (such as start, go, continue, compare), introductory words and revolutions of similar semantics). Their common function is the segmentation function, that is, "dismemberment and at the same time communication of semantic fragments within the entire text", due to which the attention of the addressee focuses on the stages of developing the topic and establishing the semantic significance and interconnection of individual fragments in the whole text [Strizhenko, Kruchinina, 1985, p. 70]. The term "bundle" will be used to designate an individual unit of this kind. Due to the "interlocking" role of connectives in the text, as well as their widespread use of not one, but several, moreover, sequentially and interdependently, it is possible to apply the concept of chain, namely chain of thought, to connective units. If the thematic chain is connected with the topic and thesis of the text, then the chain of heal) thoughts is connected with the logical scheme of the text, with the author's formation and deployment of the topic. Special means of logical division of the text, or logical connectives, can be classified on their own substantive grounds (see the experience of such classifications in the works: Malov, 1970; Akishina, 1979). Linguistic connectives are identified and actively used in the process of teaching foreigners speech activity [see, for example: Barykina et al., 1978]. In the present work, the following classification is used, developed on the basis of those mentioned above. In the structure of logical connectives, two groups are distinguished: actually logical and compositional-logical. The first includes ligaments that indicate the type and nature of previous or subsequent information, i.e., the actual meaningful links of fragments. Distinguishing objective and subjective logical as the main types of information, we name the most common types of information segments of the text. With regard to the objective-logical program of the text, using special connectives in various texts, information is distinguished: basic, typical, additional, detailing, homogeneous, distinguishable from the general series, comparable with the known one, obtained from certain sources, illustrative, etc. Each of the information-specific varieties of text fragments has, as a rule, a variety of composition and stylistic linguistic means of input into the text. For example, a fragment of text containing typical information can be entered using the following bundles: as a rule, typical, characteristic, usually, most often, in most cases, as is customary, as always, etc.; for the introduction of information indicating its source, ligaments are used: in the words (opinion, data, statement, considerations, message); as affirms (notes, notes, reports, indicates, considers, says, writes, etc.); considered (said, wrote, noticed, etc.). The subjective information of the text is emphasized either by entering connectives of the estimated content (reliability, probability, degree of difficulty of perception and other properties of the objective logical thesis can be evaluated), either with the help of connectives indicating an emotional assessment of the displayed, or by using connectives highlighting the author's position. Compare accordingly: of course, it is difficult to believe, doubtful, easy to notice; it's good that ... is the first subtype; unfortunately, fortunately, it is surprising that ...; glad that ... is the second subtype; in my opinion, in our opinion, 
the author believes, I think - the third subtype. Varieties of subjective-informative connectives correspond to semantic subtypes of rational and emotional assessment and are multifunctional. These ligaments can be considered not only as independent units of the linear category of logical content, but also as components of the field categories of tonality and evaluative. The second group of logical connectives (compositional-logical) includes units indicating the location of a fragment in the text and its spatial relationship to other fragments. These are means of compositional and structural communication of information fragments in the text. They mark the location of fragment a at the beginning, middle or end of the development of the topic, as well as in a series of fragments of the same type, the connection of one fragment a with another, preceding, or, more rarely, subsequent, etc., for example: start with ..., we turn to ..., first of all, it was noted above, I have already said, so, in conclusion, and others. We note the complex functional and semantic nature of some connective units. So, the linguistic signals of the generalization of information produced on a logical basis, at the same time, indicate the repeated nature of this information and spatial relationships in the text: the generalization, preceded by a special language reference to it, appears in the text after a number of particular provisions. Logical and informative division of the text is carried out sequentially, and, it would seem, the linguistic connectives that determine the features of individual fragments from the point of view of the logical and spatial and textual, should form a chain of relatively large, up to the general textual length. But, as a rule, the chains of thought are relatively short and intermittent. Most often, not the whole text is built with the help of the chain of thought, but its structurally-substantive part corresponding to one of the sub-theses; moreover, ligamentous means are often used to connect elementary nominations. They interrupt when the formation of the next logical sub-thesis begins in the text, the chain of thought in one way or another is realized in the next semantic block of the text, and so on to the end. The text has a certain number of private chains of thought. An outfit with them, it can also have (but not necessarily) an end-to-end similar chain. Thus, the length of the action (the term by A. A. Akishina) of logical connectives with informative division of the text is usually less than the text, but more than a single super-phrasal unity, and there may be deviations in scale in both directions: the connection of "point" elements of the text and the connection of fragments on the scale of the whole text. Elementary relationships are not analyzed in this article. In determining the chains of thought, the following textual feature was taken into account. As a rule, a fragment marked with a special ligament is linked to an unlabeled fragment. For texts of various nature, pairs of fragments are typical, in which the second fragment is communicatively weak, containing a logical connective in the preposition that connects it to the communicatively strong first fragment, for example: In the process of substantiating basic and clarifying concepts, the author turns to different theories. In the plan under consideration, the use of these concepts demonstrates empirical activity in the center of which ... (statement 1 is communicatively strong, unmarked). In particular, empirical generalizations regarding the basic concepts of the article are justified ... (statement 2 is communicatively weak, contains private information, which is marked by a prepositive logical connective - an introductory phrase in particular). The linguistic components of the chains of thought can be of different stylistic colors, textual significance, etc. - similar to the components of thematic chains. Their functional style variables are: a set of ligamentous means, taking into account the stylistic coloring and the nature of variation; the length of the action of the ligaments and the length of the chain; textual significance of certain components; placement of ligaments in the text space. Most variables coincide with similar values of thematic chains. Tonality of the text communicating through speech, we can never completely abandon our own "I". S. Balli wrote: "The effort made by the mind to get closer to objective reality is almost always in vain, because we are slaves of our own self, we constantly mix it with the phenomena of reality, and the latter is not reflected, but refracted in us" [1961, p. 22-23]. In other words, a person reflects in his speech not only the topic that interests him, but also himself. The signals of the psychological attitude of the author of the text, conscious or subconscious, pass through the entire text, creating one of the through threads that hold it together. For 4 of these signals, a certain psychological coloring of speech is created - the tonality of the text (in another terminology - subjective modality). The absence of tone signals is significant and indicates a neutral tone. Each functional style has its own range of keys, within which the author is free to choose the key that is most appropriate for his purpose, speech, addressed, his own temperament, etc. The key, or emotionally expressive content, is the text category in which he finds reflection of the psychological attitude of the author of the text. The pitch field contains the psychological self-disclosure of the author, which, according to the law of emo- 
tional infection, has the effect of increased influence on the addressee of the text [Telia, 1986]. The term "tonality" is preferred to the term "subjective modality" as a more specific one. The basis of modality as a language category is the evaluation category [Lyapon, 1971], but the author's assessment of the displayed, speech partner or himself can be both logical and superlogical (emotive) in nature. The tonality of the text is understood in this work as a functional-semantic category associated with linguistic categories of emotionality - that is, evaluations on an emotional basis [Ivin, 1970], amplification and volition, while subjective assessments of a logical nature represent the second component of subjective modality and, accordingly, a special textual category of evaluation (see below). At the pre-textual (linguistic) level, the basic means of tonality are linguistic units that directly express the semantics of emotionality, amplification, expression of will: emotional interjections, emotionally expressive., Vocabulary, words with suffixes of subjective evaluation, expressive intonational constructions, direct and figurative forms of mood, expressive syntactic constructions, special expressive techniques (trails and stylistic figures). The periphery of the linguistic field of tonality is composed of units with indirect expression of emotionally expressive semantics: neutral vocabulary with emotional connotation and in emotionally expressive use, more neutral words denoting concepts of emotions and volition, etc. It is obvious that the periphery of this field is extremely vast and strongly biased in speech. We add here also such actual speech methods of transmitting emotionally expressive content as phrasal rhythm and meaningful event transmission of emotional tension. At the text level, the core of the tonality field can be a composition of various units, both on the basis of their level language affiliation, and, most importantly, on the language status of basic or additional units. Here, as in the case of linear categories, we will distinguish between basic / additional components in the pre-text approach and main / minor ones in the textual approach. The basic units that form the core of the tonality text box are qualified as such on general grounds - in accordance with their increased significance in the text and their significant role in expressing the psychological position of the author. The text variables of the tonality field are: the composition of the core and periphery; open or hidden nature of emotional and volitional author's expression; uniformity / heterogeneity of the text in an emotionally expressive sense; placement of tonality in text space; the presence / absence of standards and design techniques for organizing language tools.
Assessment of the text, as already noted above, assessment in this paper is delimited from emotionally expressive content and, therefore, is associated exclusively with rational (intellectual, conceptual, cognitive) assessment. This assessment reflects the author's idea of the positive or negative content of the described phenomenon and the positive or negative attitude to the addressee of speech based on the logical "good - bad" dichotomy. The composition of this field in the language includes the corresponding lexical pair and its lexical-semantic variants and modifications (very good, poor, excellent, etc.), in the text it additionally includes neutral vocabulary with a rationally-estimated connotation (such as crime, embezzlement), and it also contains informative and eventful fragments related to the estimated conclusion, which is made on the basis of the social experience of the addressee and the addressee of the text (for example, in a newspaper text: Children grew up and parted. Since then, the mother has been alone. Waited, wrote letters, but received an answer did not wait - the fragment contains a hidden author's conclusion on the condemnation of children). The textual core and periphery of the ratings may coincide and not coincide with the linguistic ones. We should especially discuss the question of whether it is advisable to separate the evaluation field from the pitch field, because it is well known that in most cases a rational evaluation is associated with an emotional one, there is a complex, with two reasons, evaluation [Lukyanova, 1986]. In our opinion, the delimitation of these fields is necessary for the following reasons. Firstly, complex semantic units, rationally emotional in terms of evaluation, do not exhaust the volume of evaluative linguistic means. A number of lexical units is characterized by only one type of appraisal, with the nuclear units of both fields remaining outside the complex - rationally-estimated adverbs in the area of the field of ratings and emotional interjections in the field of the field of emotions. Secondly, presumably, the preference for a purely emotional or purely rational assessment is a differentiator of functional styles: in general, it is known that fiction eschews rational evaluations, and the scientific alienates emotional ones. At the same time, the textual categories of tonality and appraisal can be considered as particular categories in relation to the category of text modality (subjective modality) that is generic to them. Textual functional style variables of the categories of appraisal and tonality are similar, we note only the special significance of the open or hidden nature of the rational appraisal, as well as its homogeneity or heterogeneity. Temporality of text (text time) time and space are 
universal properties of all material things, necessary conditions for the existence of a world of phenomena. The text as a reflection of a certain fragment of reality and a certain situation of communication also cannot exist outside these properties. In this regard, the statement of M. Bakhtin that "any entry into the realm of meanings is made only through the gates of the chronotopes" [1975, p. 406], it seems, can be attributed not only to the literary, but also to any other text. The structure of text space and text time to a certain extent models real space and time, but, of course, it cannotbe reduced only to such a model [Lotman, 1970; Karimova, 1985]. It should be borne in mind that in the text - the author's, subjective speech product - real time is reflected through its subjective perception, i.e. real time is combined here with perceptual time associated with the perception of real reality (for varieties of the philosophical category of time see: Mostepanenko, 1969) The degree of influence of perceptual time can be different from the minimum in "objectified" texts of the scientific type to the maximum in individualized texts of the artistic type, where perceptual time is additionally combined with the individual and a new phenomenon is born - artistic time, with its special features not characteristic of real time, multidimensionality, reversibility, unevenness, etc. [Turaeva, 1979, p. 16-27]. The synthesis of reflected real and perceptual time with the prevailing role of the first, when the displayed is associated with a specific moment or period of the subject's life, national or world history, will be called objective text time [Moskalskaya, 1981]. Objective time in the text is a relatively adequate reflection of real time (empirical, historical, calendar). In addition to the objective text, conceptual time can be characteristic of the text, which is understood as the reflection of real time at the level of ideal entities derived from an analysis of reality - concepts and concepts [Mostepanenko, 1969, p. 5]: The difference between objective and conceptual time is point of reference and various correlations with extralinguistic reality [Turaeva, 1986, p. 96]. The reference point is an extremely important point in the concept of time and the temporal structure of the text. This is a kind of conditional "now", "now", starting from which it is possible to build the temporal perspective of the text and other temporal relationships. The reference point can be objective in nature, that is, refer to real time, and can be relative, having a conditional character. In turn, a relational, conditional reference point can indirectly go to the line of objective time ["the time moment of any event that has become the subject of a message and, therefore, already in a certain way correlated with the absolute reference system can act as a relative reference point" [Desherieva, 1975 , p. 116].

\section{REFERENCES:}

1. Акишина А. Л. Структура всего текста В 2-х частях. М., № 79. Часть 1. с.89

2. Барт Р. Анализ текста // Новое в зарубежной лингвистике. М., 1980. С. 307-312.

3. Барыкина А.И., Бурмистрова В.П., Добровольская В.В. Пособие по развитию навыков письма. М., 1978. $190 \mathrm{C}$.

4. Гак В. Г. Повторная номинация и ее стилистическое использование // Вопросы французской фрилологии. М., 1972. С. 123-136.

5. Гак В. Г. О семантической организации текста // Лингвистика текста: Материалы науч. Конф.: В 2-х частях. М., 1974. Часть 1. С. 61-66.

6. Гак В. Г. К типологии языковых номинаций // Языковая номинация: общие вопросы. М., 1977. С. 230-293. Гришина О. Н. Проблемы контекстного разделения текста в стиле языка художественной и научной прозы // Функциональные стили и преподавание иностранных языков. М., 1982, с. 52-68.

7. Дридзе Т. М. Текст как иерархия коммуникационных программ: (информационно-целевой подход) // Смысл восприятия речевого сообщения. М., 1976, с. 48 - 57.

8. Дешериева Т. И. Лингвистический аспект категории времени в ее отношении к физическим и философрским аспектам // Вопросы языкознания. 1975. № 2. С. 111-117.

9. Ивин А. А. Основы логики оценок. М., 1970.230 с. Леонтьев А. А. Поговорка как предмет лингвистики, психолингвистики и теории общения // Синтаксис текста. М., 1979. С. 18-36.

10. Ляпон М. В. К вопросу о языковой специфике модальности // 1971. Т. 30, № 3. С. 230-239.

11. Майданова Л. М. Очерки о практическом стиле: Для студентов-журналистов Свердловск, 1986. 184 с.

12. Мамалыга А. И. Структура газетного текста. Киев, 1983. 137 с.

13. Мете Н. А., Митрофанова О. Д., Одинцова Т. Б. Структура научного текста и преподавание монологической речи. М., 1981. 144 с.

14. Мостепаненко А. М. Проблема универсальности основных свойств пространства и времени. Л., 1969. 229 с. Москальская О. И. Грамматика текста. М., 1981. 183 с.

15. Новиков А. И. Семантика текста и его формализация. М., 1983, с. 215

16. Откупщикова М. Н. Некоторые закономерности распознавания связного текста. Лингвистические проблемы функционального моделирования речевой деятельности. Л., 1982. Выпуск. 5. С. 21-41. 
17. Откупщикова М. И. Синтаксис связного текста: (Структурная лингвистическая модель), 1987. 33 с.

18. Ризун В.В. К теме текста и тематической группе слов: теоретический аспект // Язык и состав газетного текста: теория и практика. Свердловск, 1987. С. 32-37.

19. Сметанина С. И. Функционально-типологический анализ методов именования лиц и фрактов в структуре публицистического текста: Л., 1982. 16 с.

20. Семантическое восприятие речевого общения: (в условиях массовой коммуникации). М., 1976. 263 с.

21. Стриженко А. А., Кручинина Л. И. Об особенностях организации текстов, относящихся к разным функциональным стилям. Иркутск, 1985. 176 с.

22. Теля В.Н. Коннотативный аспект семантики номинативных единиц. М., 1986. 142 с.

23. Тункель В. Д. К вопросу о устной передаче речевого сообщения: Дис. кандидат филол. наук. М., 1964.

24. Тураева 3. Я. Лингвистика текста. М., 1986. 126 с.

УДК 811.133.1

DOI https://doi.org/10.32782/tps2663-4880/2020.13-1.29

\title{
ОСОБЛИВОСТІ МОДЕЛЮВАННЯ ЛІНГВОКУЛЬТУРНОГО TИПАЖУ ВОВО PARISIEN
}

\section{FEATURES OF THE MODELLING OF LINGUOCULTURAL TYPE OF BOBO PARISIEN}

\author{
Тарасюк I.B., \\ orcid.org/0000-0003-3417-2671 \\ кандидат філологічних наук, дочент, \\ доиент кафедри романської філології і перекладу \\ Запорізького національного університету
}

\begin{abstract}
Статтю присвячено моделюванню лінгвокультурного типажу «bobo parisien» як досить впізнаваного представника французької лінгвокультури, а саме ії заможного та культурного прошарку. Дослідження виконано на стику лінгвоконцептуального та лінгвокультурологічного напрямів сучасної лінгвістики. У межах лінгвоконцептуального напряму мовні одиниці розглядаються як засоби репрезентації концептуальних структур, а лінгвокультурологічний підхід інтерпретує мовні знаки як результат взаємодії мови і культури в процесах безпосередньої комунікації. Лінгвокультурний типаж «bobo parisien» може бути віднесений до соціокультурних, оскільки об'єднує людей різних соціопрофесійних груп, яким властивий особливий тип мислення, комунікативної поведінки та ціннісні установки. Мета аналізу - описати понятійні, образно-перцептивні, оцінні та ціннісні характеристики лінгвокультурного типажу «bоbо parisien» у французькій лінгвокультурі. В якості практичного матеріалу слугували фрранкомовні тлумачні словники, дані соціологічних досліджень, публіцистичні тексти Інтернет-видань, відео, інтерв'ю. Моделювання лінгвокультурного типажу «bobo parisien» велось із застосуванням концептуального, семантичного та інтерпретативного методів дослідження. Результати засвідчили, що лінгвокультурний типаж «bobo parisien» знаходиться на етапі свого фрормування. Тлумачні словники демонструють коливання в доборі понятійних ознак у своїх дефініціях. Головною рисою лінгвокультурного типажу «bobo parisien» $€$ його контроверсійність, яка проявляється в суперечливості оцінок. Вивчення лінгвокультурного типажу сприяє кращому розумінню змін, які відбуваються у французькій лінгвокультурі, та дозволяє визначити специфрічні для неї процеси.
\end{abstract}

Ключові слова: лінгвокультурний типаж, концепт, лінгвокультура, конститутивні ознаки, ціннісні домінанти.

The article deals with the modeling of the linguocultural type "bobo parisien" as a typed representative of a wealthy and cultured layer of modern French society. The research was performed at the intersection of linguoconceptual and linguocultural trends of modern linguistics. The first studies linguistic units as a means of representing conceptual structures, and the second interprets linguistic units as a result of the interaction of language and culture in the processes of direct communication. The linguocultural type "bobo parisien" can be referred to as socio-cultural because it brings together people of different socio-professional groups, which are characterized by a particular type of thinking, communicative behavior and value attitudes. The purpose of the analysis is the conceptual, figurative-perceptual, evaluation and value characteristics of the linguocultural type "bobo parisien" in French linguoculture. Practical materials were French-speaking dictionaries, sociological research data, journalistic texts of online publications, video interviews. The modeling of the linguocultural type "bobo parisien" was conducted using conceptual, semantic and interpretative research methods. The results showed that the linguocultural type "bobo parisien" is at the stage of its formation. Frenchspeaking dictionaries vary in the definition of conceptual features of this type. The main feature of the linguocultural type "bobo parisien" is its controversial character, which manifests itself in the contradiction of assessments. The study of linguocultural type contributes to a better understanding of the changes that are taking place in French linguoculture and allows to identify processes specific to it.

Key words: linguocultural type, concept, linguoculture, constitutive features, value dominants. 